\title{
Intermarriage and Segmented Integration into Finnish Society: Immigrant Women from the Former Soviet Union
}

\author{
ANNI JÄÄSKELÄINEN, M.Soc.Sc., Researcher \\ Rehabilitation Foundation, Helsinki, Finland
}

\begin{abstract}
The number of immigrants is still very small in Finland. Until the 1990s immigrants came to Finland in small numbers, mostly as a consequence of marriage. With the dissolution of the Soviet Union, immigration to Finland from the former Soviet Union has increased considerably with the consequence that Russian and Estonian speakers in Finland form the biggest immigrant groups speaking a foreign-language. Nowadays the largest immigrant groups from the former Soviet Union consist first of 'ethnic returning migrants' with Finnish ancestry and their family members and second of immigrants married to Finnish citizens. In this article the social and economic integration of immigrant women from the former Soviet Union into Finnish society was explored, with reference to the concept of segmented integration. Intermarriage is often defined a priori as 'problematic' and it is thought to generate conflict, marginality and isolation for the immigrants. On the other hand, intermarriage is also seen as a resource for integration and social inclusion for the foreign-born. In this study intermarried immigrant women (Finnish-born - foreign-born couples) were compared to in-married immigrant women (foreign-born-foreign-born couples) using a nationwide population survey targeted at Russian and Estonian immigrants from the area of the former Soviet Union.
\end{abstract}

The results show that intermarried immigrant women seem to be quite successful in finding access to the Finnish and co-ethnic networks and at the same time they were economically integrated. In-married immigrants experienced economic limitations more often than those who were intermarried. A noticeable part of in-married women actually integrate into the networks of co-ethnics, while integration into Finnish networks is weak or non-existent. Intermarried immigrant women, on the other hand, integrate more often only into the Finnish community. This indicates that integration has become segmented and that marriage type was an important element - but only one among other factors - in the process of segmented integration.

Keywords: Intermarriage, immigrants, integration, Finland, the former Soviet Union 


\section{Introduction}

At the end of the twentieth century there have been vast population movements in the Western industrial countries caused by work migration, refugees, tourism and so forth, which bring more people than ever before into contact with each other. At the same time an increase in the intermarriage rates has been a significant family and demographic trend, which can be seen also in Finland. At the end of 2001 almost one out of every three immigrants in Finland had a Finnish-born spouse when cohabiting partners are included (Statistics Finland 2002). The fact that intermarriages are common is often forgotten when the integration of immigrants is discussed and studied. In Finland marriage was the starting point for the integration of the majority ${ }^{1}$ of intermarried immigrants from the former Soviet Union (FSU).

It has become important to understand the 'forces' that influence the integration of immigrants. The purpose of this study was to describe the diverse possible outcomes of the integration of intermarried and in-married immigrants, with reference to the concept of segmented integration. Intermarriage means here a marriage between a Finnish-born Finnish citizen and a foreign-born immigrant from the FSU. In-marriage is a marriage within a group, here between immigrants from the FSU. 'Intermarriage' and 'in-marriage' also include cohabitation. Different marriage types were compared using a nationwide population survey targeted at Russian-speaking and Estonian immigrants, the main immigrant groups in Finland. I explored whether in- and intermarried immigrant women from the FSU were integrated into the social networks and institutions of the Finnish core society, or if they gave preference to immigrant networks and communities, thereby indicating segmented integration.

The theory of 'segmented assimilation' describes the diverse possible outcomes of the process of the adaptation of immigrants and is used for developing a typology of resources and vulnerabilities affecting such outcomes (Portes and Zhou 1993; Zhou 1997). Portes and Zhou observed that immigrant groups did not assimilate into a relatively uniform mainstream in the USA. Instead they found three possible 'patterns of adaptation', which were most likely to occur among contemporary immigrants. First was acculturation and parallel integration into the white middle class. Second was acculturation and integration into the underclass and the third associates rapid economic advancement with slow acculturation and deliberate preservation of the immigrant community. (Portes and Zhou 1993, 82.) The theory attempts to explain what determines into which segments of the host society a particular immigrant group may 'assimilate' (Zhou 1997, 984).

\footnotetext{
1 In our data $81 \%$ of intermarried immigrants (including those who were cohabiting) obtained an entry visa by marrying a Finnish citizen. The majority of immigrants from the former Soviet Union are women In our data half of the married (or cohabiting) women are married to a Finn, but only one in ten intermarried men. The clear majority of the intermarried women obtained their entry visa by marrying a Finnish citizen ( $85 \%)$, but only half $(47 \%)$ of the intermarried men obtained theirs this way.
} 
Portes and Zhou use the terms assimilation, adaptation and integration quite freely, almost as synonyms (Portes and Zhou 1993; Zhou 1997). According to Carmon assimilation is a process by which immigrants adopt the lifestyles and norms of the host society in a way that leads to the disappearance of a distinct immigrant group (Carmon 1996, 23). Intermarriage has been seen as one form of assimilation (Gordon 1964). Social reality and empirical evidence do not, however, support the idea of inevitable assimilation (Carmon 1996, 23). In this article I used instead the term integration, meaning a process in which the immigrant integrates into the host society and/or coethnic society. Integration toward the host society can be called external integration, which includes different components: political, economic and social integration (Forsander 2001, 31; Ekholm 1994). In this study only economic and social integration was studied. The second fundamental part of integration is internal integration, which describes the cohesion of the co-ethnic community and the immigrants' social integration into it (Schierup and Ålund 1987, 18). I use the term 'segmented integration' to explain diverse possible outcomes of both internal and external integration.

The spouse not only provides emotional support in getting used to the new society, she or he is also expected to help in different areas of daily life, e.g. looking for housing, work and entrance into social networks. The nationality of the spouse may influence his or her recourse to help. My hypothesis was that the spouse who is a native member of the host society has more resources to help in external integration while an immigrant spouse has more resources for internal integration, with this being one of the reasons leading to segmented integration.

In most of the studies about intermarriage, it is seen a priori as 'problematic' (Breger and Hill 1998) and it is thought to generate conflict, isolation or marginality for immigrants and their spouses in Western-non-Western marriages (for a review, see Cottrell 1990; Imamura 1990). On the other hand, intermarriage has been seen as a resource for integration and social inclusion for the foreign-born. The nationality of the spouse is thought to be an important factor promoting integration, according to studies made by Ylänkö about Africans in Finland (1997) and Tuomi-Nikula about Finns married in Germany (1987).

Castrén (2001) has characterized three possible roles of the spouse in the formation of social networks in her study of teachers' social networks in Helsinki and St. Petersburg ${ }^{2}$. First, spouses may help in the process of social mobility, second, they can introduce new 'cultural milieus' (such as a new culture or lifestyle), and third, they may assist in settling into a new place of residence. In Finland the first two roles were particularly important, while in Russia only the third role had real significance. According to

\footnotetext{
2 The data were collected in 1993 - 1994 and include information about the social networks of 78 secondaryschool teachers. Information was gathered from diary questionnaires and interviews of teachers' life courses.
} 
Castrén it seemed that the role of the spouse in the formation of the wife's or husband's networks was less significant in St. Petersburg than in Helsinki. Spouses in Russia often have networks of their own, while spouses in Finland more often have a shared network, e.g. a larger marital network. If spouses have networks of their own, there would not be much difference between the networks of in- and intermarried immigrants. If spouses have only or mostly shared Finnish networks, if the Finnish spouse assists a lot in the process of settling into Finland and the immigrant spouse is unemployed or in a low-paying job, the situation may cause economic, social and informational dependence on the Finnish spouse (Jaakkola 1994).

The present study used data collected in 2001 in a representative nationwide population survey focused on Russian-speaking and Estonian immigrants (aged 18-65), who had moved to Finland before the year 2000. This survey data provides an abundance of information on the background of the respondents, the living conditions, social networks and economic situation of the immigrants. Because the sample was a representative one, immigrants with either Finnish or some other citizenship were included, as were immigrants living in rural settings.

\section{Recent immigration to Finland}

Finland has historically been a country of emigration and has never received flows of labor immigration. The number of immigrants is still very low in the Western European context: there were only 145,135 foreign-born immigrants (2.8 percent of the population) in 2000 (Statistics Finland 2002, 14), but the relative increase in the beginning of the 1990s was substantial. This means that most immigrants have lived in Finland for a short time and the increase of immigration happened when Finland was struck by a severe economic depression.

There were 38,000 immigrants born in Russia or the Soviet Union and 9,000 immigrants born in Estonia living in Finland in 2001. As to language, Russian was the most common foreign language (31,000 Russian speakers), followed by Estonian (11,000 Estonian speakers). A clear majority of the immigrants from the FSU were of working age. (Statistics Finland 2002, 16, 10.)

Earlier immigrants came to Finland in very small numbers, mostly as a consequence of marriage with a Finnish citizen. At the end of the year 2001 there were altogether 40,000 foreign-born spouses (including cohabiting partners) of persons born in Finland (Statistics Finland 2002). Two-thirds of the immigrants from the FSU now living in Finland are women. The predominance of women is a consequence of marriages between Finnish men and Russian or Estonian women. Finnish men marry foreigners almost as often as Finnish women do. In 2001 foreign-born spouses and cohabiting partners of men born in Finland were most often from Sweden, the FSU (including 
Russia), Estonia and Thailand. When a Finnish woman's spouse is a foreigner, his country of birth is also most often Sweden or the FSU (including Russia), but the latter marriages are almost six times as common among Finnish men compared to women. Finnish men who married foreign-born women in 1991-2001 most often married women from Russia, Estonia, the FSU and Thailand. When Finnish women married foreign-born men during the same period, the husbands were most often from the USA, Turkey, the United Kingdom, Sweden and Germany. (Statistics Finland 2002.) It is interesting that recently intermarriages have been asymmetrical in Finland: men found their foreign spouses generally from the east and women from the west and the south.

The inflow of ethnic Finns began in the early 1990s, when the status of "returning migrant" was accorded to people in Russia, Estonia and other parts of the former Soviet Union who were of Finnish descent. This led to an immediate increase in immigration. The immigration movement of "returning migrants" was not related directly to economic factors such as recruitment programs. It was connected to ethnic and historical factors (Laari 1997). Similar ethnic migration movements can be found, one example being the Jewish migration to Israel and another that of ethnic Germans to Germany (Shuval 1998; Dietz 2000). In fact, there are many categories of "returning migrants". Those who are of Finnish descent refer mainly to two groups of immigrants from the former Soviet Union. The first and biggest group mostly represents Ingrian Finns, who are descendants of Finns who emigrated from the beginning of the 17th century to rural Ingria, which is located partly in Russia and partly in Estonia. The second group is formed by descendants of Finns who migrated to the territory of the former Soviet Union during the 1920s and 1930s, mostly for political reasons and because of the economic situation in Finland. Many persons who have moved to Finland under the status of "returning migrant" are not of Finnish descent and have arrived as spouses of mixed marriages. Many young people have migrated as family dependents. (Jasinskaja-Lahti 2000, 17-19.)

Many ethnic Finns and especially their relatives are not proficient in Finnish. This must be attributed to the minority status held by the Finns in the FSU. Finns were identified as such by the state authorities in the passport and registration system, but many ethnic Finns lost their ties to the Finnish culture and language. The process of assimilation was often enforced by the Soviet state through an assimilation policy, ethnic discrimination and forced migration, e.g. to Siberia, which led to ethnic diaspora and intermarriage (mainly Russian/Finnish). According to Eve Kyntäjä (1997) different age groups among the Ingrian Finns have different ethnic identities. Younger "remigrants" identify themselves mostly as Russians and Estonians, depending on which linguistic and social environment they have lived in. Middle-aged Ingrian Finns have problems in identifying themselves ethnically and in integrating into Finnish society. The elderly Ingrian Finns were born to Ingrian parents and their mother tongue is Finnish. They have usually been deported or imprisoned and have lived in exile. 
This group has a strong Finnish identity. The most common reasons for remigration are the unstable economic situation in Russia and their feeling of insecurity. (Kyntäjä 1997.)

\section{Data and methods}

This study used data gathered in 2001 in a representative nationwide population survey, stratified by gender and ethnic group and targeted on immigrants born in the FSU who were aged 18-65 and who had moved to Finland before the year 2000. This study was part of the research project 'Developing theory and methodology in the study of the effects of discrimination and marginalization ${ }^{3}$.

The study was conducted as a postal survey by Statistics Finland in Estonian, Finnish and Russian. The total response rate was 63 percent: for Estonian men it was 55 percent, for Russian men 56 percent and Russian women 65 percent. Estonian women had the highest response rate: 72 percent. There were a total of 2,360 cases. The data was weighted for analysis using the actual size of the Russian and Estonian immigrant groups in Finland. Only those immigrants who were married or living in non-formalized unions at the moment were analyzed in this study. There were only 61 intermarried men in the sample (compared with 538 in-married men after weighting). Because of this and the difficulties in comparability between intermarried men and women, only the results concerning women are presented ( $\mathrm{N}$ after weighting was 1,338).

Russians include all Russian speakers born in the FSU, including Estonia. Estonians include Estonian speakers born in the FSU. Ethnic Finns were separated from these groups (which originally also included those immigrants who where Finnish speakers) by using information about the respondent's parents' ethnicity. If one parent was Finnish, the immigrant was included among the ethnic Finns.

Active labor force participation, home ownership, a normal or spacious housing density and the good economic situation of the family indicate greater access to economic resources. Financial security guarantees many possibilities and a lack of economic resources impedes choice and induces powerlessness. This applies to everybody, both native Finns and the foreign-born. Economic integration was measured by the following indicators:

\footnotetext{
3 The project is led by professor Karmela Liebkind (University of Helsinki) and the following researchers are also taking part in the research: Magdalena Jaakkola (Rehabilitation Foundation), Inga JasinskajaLahti (University of Helsinki), Liisa Kosonen (City of Espoo), Eve Kyntäjä (University of Helsinki) and Simo Mannila (Rehabilitation Foundation). The survey questionnaire was designed by the abovementioned project members, with Anni Jääskeläinen (Rehabilitation Foundation) joining the project afterwards. The project is part of the research program on 'Marginalization, Inequality and Ethnic Relations in Finland' (SYREEND), supported by the Academy of Finland.
} 
1) Type of activity. Employment or some other socially accepted activity is crucial for the integration of immigrants. The following classification was used: (1) not unemployed at the moment (employed, entrepreneur, student or other person not part of the labor force) and (2) unemployed at the moment.

2) Economic situation of the family was measured using a subjective assessment. The following classification was used: (1) good economic situation (no reduction in consumption - only some reduction in consumption) and (2) bad economic situation (much reduction in consumption - cannot manage economically). In addition to the labor market, the welfare system and the family represent the foundations for the individuals' ability to support herself or himself.

3) Housing. First housing tenure was described using the following classification: (1) homeowner and (2) tenant (rented housing, employer-provided, similar arrangement or other). Owner occupancy is a sign of permanence, of the intention to stay and the family's social and economic status in Finland and can be interpreted as an indicator of integration into the middle class. The housing density classification was (1) normal or spacious and (2) overcrowded. The dwelling was classified as overcrowded if there was more than one person per room, with the kitchen excluded from the analysis.

Social integration into the Finnish and co-ethnic community was measured by personal networks. Personal networks were defined as ties of kinship and friendship, and measured by meeting co-ethnic and Finnish relatives and/or friends at least once a month.

The research methods utilized for studying social and economic integration were crosstabulation and logistic regression analysis. In the logistic regression model, economic integration was measured by a dichotomy of the accumulation of indicators ( $0-2$ vs. 34 indicators). Accumulation of economic integration included the following four indicators: type of activity, economic situation of the family, housing tenure and density. The explanatory variables were introduced in the following order: gender, age, ethnic background of the respondent, education, nationality of the spouse, year of migration, Finnish language proficiency and place of residence. The first characteristics of the individuals were irreversible: once ascribed they cannot normally be changed. The second types of variables were reversible and potentially they can be influenced by the person him/herself at a later stage in life. The same set of background variables was used in all analyses. The main idea was to compare which variables explained different segments of integration. 


\section{Background of in- and intermarried women immigrants}

Intermarriages were common among immigrant women from the FSU living in Finland. One-third (32\%) were married to a Finn and 40 percent to another immigrant. So almost half ( $45 \%$ ) of the married (or cohabiting) women in our data were intermarried at the time of the study. The clear majority of intermarried women obtained an entry visa by marrying a Finnish citizen ( $85 \%$ ), while the clear majority $(75 \%)$ of in-married immigrants obtained an entry visa as "a returning migrant" (including spouses of ethnic Finns).

Table 1 presents the background of in- and intermarried immigrant women in Finland. Most of the intermarried women from the FSU were Russians, with the Estonians being the second largest group. The minority of intermarried women were ethnic Finns. However, half of the in-married immigrants from the FSU were of Finnish descent, $40 \%$ were Russian and just over 10\% Estonian. A small inter-ethnic distance from the dominant culture is a factor promoting integration into the host society. Integration is easier if the immigrant is of the same religion and cultural family as members of the dominant culture (Padilla 1980, 49-50). Given the similarity of the Finnish and Estonian language and culture, it may be much more easier for the Estonians to integrate into Finnish society. The same may be true for those ethnic Finns who have Finnish as their mother tongue and a Finnish identity.

Estonians and especially "Ingrian Finns" were much more accepted by Finns as migrants to Finland than were Russians. (Jaakkola 2000.) The popularity of Ingrian Finns in Jaakkola's study could be explained by the romantic images of Ingrian Finns and the fact that they are in fact "Finns" (Kyntäjä 1997). Russians and ethnic Finns, who also are often Russian speakers, face more discrimination in Finland than Estonians (Jasinskaja-Lahti, Liebkind and Vesala 2002, 123). Negative attitudes and discrimination raise special concerns for the integration of Russians and Russian-speaking ethnic Finns in Finland.

A number of universal factors influencing integration have been distinguished including age and time of immigration: a young age and long period as an immigrant accelerate integration. Intermarried immigrant women migrated a little earlier (one year) on average to Finland than in-married women. Intermarried immigrant women were also somewhat younger (an average age of 29) when they migrated compared to inmarried women (an average age of 33). In these respects it may be easier for intermarried immigrants to integrate into Finnish society than for in-married women.

In general, immigrants from the FSU were well educated. Intermarried immigrant women had a university or high occupational degree somewhat more often $(43 \%$ of women) than in-married women ( $33 \%$ of women). Only $4 \%$ of all women had just a primary education or less. The differences between in- and intermarried women were 
not so clear concerning pre-immigration occupations. Half of the immigrant women from the FSU had a profession before moving to Finland. Immigrant women from the FSU brought with them a large amount of 'human capital', which may be favorable for integration.

Table 1. Background of in- and intermarried immigrants from the FSU (percent).

\begin{tabular}{|c|c|c|}
\hline \multirow[b]{2}{*}{ Age (average years) } & \multicolumn{2}{|c|}{$\begin{array}{c}\text { Women } \\
\text { In-marriage Intermarriage }\end{array}$} \\
\hline & $40^{*}$ & 37 \\
\hline $\begin{array}{l}\text { Age at migration } \\
\text { (average years) }\end{array}$ & $33^{*}$ & 29 \\
\hline $\begin{array}{l}\text { Years since migration } \\
\text { (average years) }\end{array}$ & $7.0^{*}$ & 8.0 \\
\hline $\begin{array}{l}\text { Ethnic background of immigrant } \\
\text { Ethnic Finn } \\
\text { Russian } \\
\text { Estonian }\end{array}$ & $\begin{array}{l}47^{*} \\
40 \\
13\end{array}$ & $\begin{array}{l}14 \\
61 \\
25\end{array}$ \\
\hline $\begin{array}{l}\text { Education } \\
\text { Primary school (or less) } \\
\text { Vocational training/ High school } \\
\text { University / High occupational }\end{array}$ & $\begin{array}{c}4^{*} \\
63 \\
33\end{array}$ & $\begin{array}{r}4 \\
53 \\
43\end{array}$ \\
\hline $\begin{array}{l}\text { Finnish language proficiency } \\
\text { (speaks Finnish well or very well) }\end{array}$ & $45^{*}$ & 68 \\
\hline $\begin{array}{l}\text { Place of residence (density of popu } \\
\text { Urban } \\
\text { Rural, densely populated } \\
\text { Rural, sparsely populated }\end{array}$ & $\begin{array}{l}90^{*} \\
4 \\
6\end{array}$ & $\begin{array}{l}68 \\
12 \\
20\end{array}$ \\
\hline Number of cases $(\mathbf{N})$ & 734 & 604 \\
\hline
\end{tabular}

* Differences between in- and intermarried immigrants are statistically significant at the 5-percent risk level. A t-test was used for equality of means. Pearson's Chi-Square was used for cross-tabulations.

Integration is easier if the immigrant can speak the language of the dominant culture, because he or she is then able to make contacts with its members. At the same time contacts - e.g. marriage - with a member of the host society makes it possible for the immigrant to learn the language. Many immigrants had learned Finnish before moving to Finland: e.g. many ethnic Finns had it as a mother tongue ( $38 \%$ of them in this study), usually in combination with another mother tongue (Russian/Estonian), and some marriages were probably possible because of language skills. In many cases, however, immigrants from the FSU are not actually skilled in the Finnish language. 
At the time of the study less than half of the in-married immigrant women spoke Finnish well or very well, while over two in three of intermarried women did so.

Both in-married and intermarried women migrants were most likely to be urban. Intermarried women were, however, more often likely to be found in densely populated rural communities ( $12 \%)$ compared to in-married immigrant women (4\%). One intermarried woman in five lived in a sparsely populated rural community, while less than 10 percent of in-married women did so. The spatial segregation of the foreign-born is not very strong in Finland (Kauppinen 2000), but in-married immigrant women (39\%) reported twice as often as intermarried women that there are many foreigners living in the same area. In towns where many immigrants live it is easier to form ethnic communities and networks. In the countryside and in small towns the supply of candidates for co-ethnic friends and spouses can be sparse as are work possibilities, but the housing situation is better.

\section{Economic integration}

The high unemployment rate of the immigrants indicates that the danger of marginalization is imminent. Intermarried women were somewhat less often unemployed than in-married immigrant women. The difference between these groups was not very big (5\%). It is clear, however, that the accumulation of unemployment is more common in the families where both spouses are immigrants. In 13\% of the families of in-married immigrant women both spouses were unemployed, compared to $4 \%$ of intermarried women $(\mathrm{p}<.000)$.

Not surprisingly, immigrant women married to other immigrants tended to live in more modest socioeconomic conditions, as indicated by the subjective economic situation of the respondent and her family. Three out of four intermarried women reported that their family's economic situation was good, but only 57 percent of the in-married immigrant women did so.

The differences between marriage types in regard to housing were clear: only one in ten in-married immigrant women owned their accommodation compared to half of intermarried women. Intermarried couples also had more living space in their homes than in-married couples: one-third of in-married immigrant women lived in overcrowded conditions, while one in four intermarried women did so. 
Table 2. Indicators for the economic integration of in- and intermarried women from the FSU (percent).

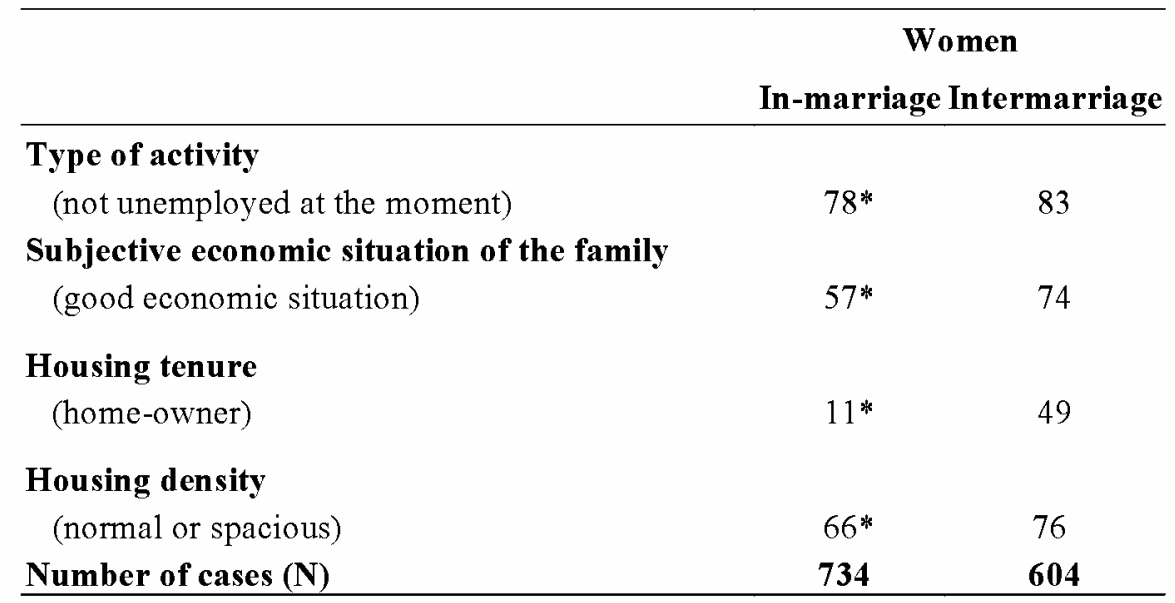

The presence of several economic integration indicators means the individual's economic position is good and the contrary means a weak and potentially exposed position. In-married immigrant women were in a weaker economic position than intermarried women when the accumulation of indicators was studied (minimum 0 - maximum 4). Intermarried immigrant women were almost twice as often (63\%) integrated in regard to at least three indicators mentioned in Table 2 compared to in-married women $(34 \%)(p<.000)$. One out of four in-married women was integrated economically in only one dimension compared to one in ten intermarried immigrant women. It was rare for immigrant women to not be integrated in any dimension at all.

Figure 1. Accumulation of economic integration indicators for immigrant women by marriage type, percent.

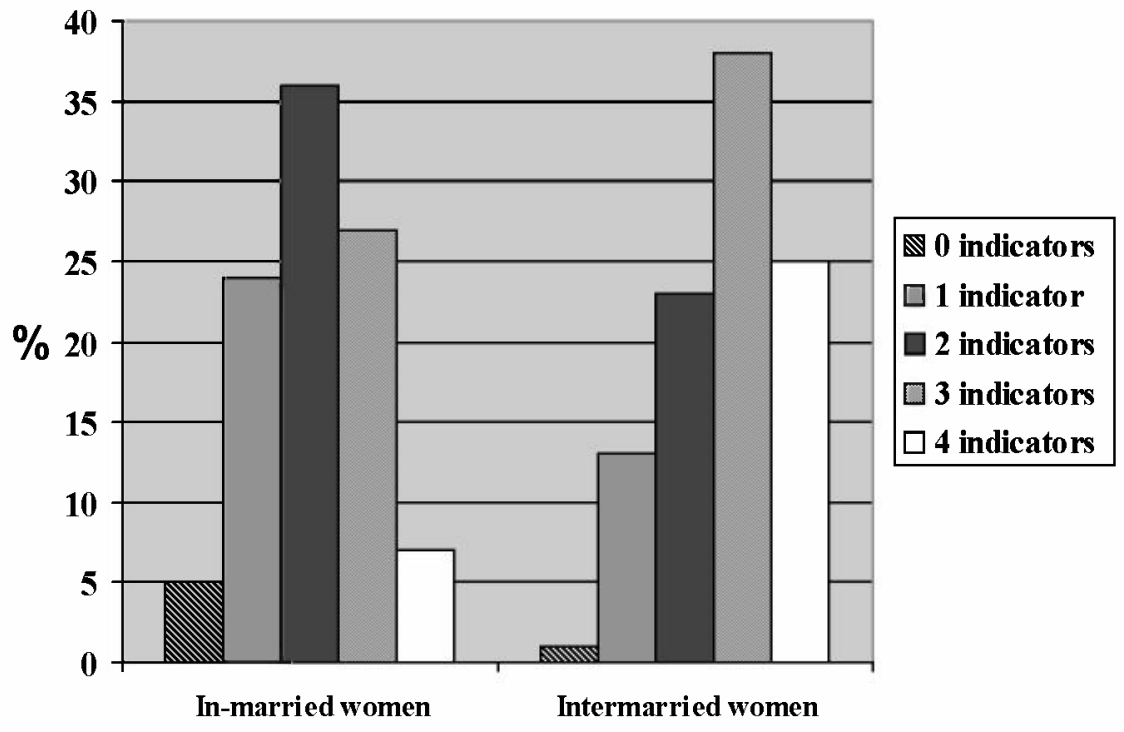


A logistic regression analysis was carried out on the accumulation of the economic integration indicators in the case of immigrant women. The main results of the analysis can be summarized as follows (see Appendix 1):

1) The oldest age group was slightly less economically integrated than the younger groups ( $43 \%$ vs. $52-53 \%$ ). These differences remained even after controlling for the possible influence of other factors. This was expected, because according to previous studies it is easier for the young to integrate.

2) Estonians were the most economically integrated group (60\%), followed by Russians (50\%) and immigrants with Finnish ancestry (39\%). The difference between Russians and ethnic Finns disappeared, however, when marriage type was controlled for. The difference was thus due to the fact that Russian women are more often married to a Finnish-born Finn than ethnic Finns are. The difference between the Russians and Estonians also increased when the influence of Finnish language proficiency was controlled for. One can then conclude that, compared to the Estonians, the Russians' economic problems were due to language problems.

3) Immigrants who had university and high occupational degrees were more economically integrated compared to immigrants with a lower education (56\% vs. $40 \%$ ). The differences between educational groups remained statistically significant even after the other factors were controlled for.

4) In accordance with the hypothesis, marriage with a member of the dominant culture was clearly more favorable for economic integration than marriage with another immigrant ( $63 \%$ vs. $36 \%$ ). The original difference between marriage types diminished slightly after the influence of other factors was controlled for, but remained big and statistically significant.

5) Year of migration had a powerful impact on economic integration. Most of the immigrant women who moved to Finland before the 1990s were economically integrated (70\%), as were half of those who moved between 1990-1994 and 41 percent of those who moved between 1995-1999. These differences remained after controlling for the other factors. With time immigrant women seem to adapt more into the Finnish economic system.

6) Proficiency in the Finnish language was also an important factor promoting economic integration. Those women who spoke Finnish well or very well were clearly more often economically integrated compared to those who spoke Finnish moderately or poorly ( $58 \%$ vs. $36 \%)$.

7) Economic integration seemed to be easier in the densely populated rural areas compared to both urban and sparsely populated rural areas (64\% vs. $46 \%$ vs $51 \%$ ). The original difference between places of residence diminished, however, once other factors were controlled for and did not remain statistically significant. 


\section{Social integration}

Table 3 shows the results concerning social integration. The majority of the immigrant women met both co-ethnic and Finnish relatives and/or friends at least once a month. This could be interpreted as a positive sign of integration. It was somewhat more common among intermarried women (76\%) to meet both co-ethnic and Finnish relatives or/and friends than among in-married women (62\%). A clear majority of both inter- and in-married immigrant women met co-ethnic relatives and/or friends at least once a month $(94 \%$ vs. $86 \%, p<.000)$. Two out of three intermarried immigrant women met co-ethnics every week as did a clear majority $(86 \%)$ of in-married women $(p<.000)$. This indicated the important role of immigrant networks for all immigrant women, not only for those married to other immigrants, although they met co-ethnics more often than the intermarried women did.

Table 3. Social integration of in- and intermarried immigrant women from the FSU (percent).

\begin{tabular}{lcc} 
Relative and/or friend networks & In-marriage & Intermarriage \\
\hline (meets every week or every month) & $62 *$ & 76 \\
Meets both co-ethnics and Finns & 32 & 9 \\
Meets only co-ethnics & 4 & 10 \\
Meets only Finns & 2 & 5 \\
Does not meet co-ethnics or Finns & 100 & 100 \\
Total & $\mathbf{7 2 9}$ & $\mathbf{5 8 5}$ \\
Number of cases (N) & \multicolumn{2}{|c}{ * } \\
* Differences between in- and intermarried immigrants are statistically significant \\
at the 5-percent risk level. Pearson's Chi-Square was used for cross-tabulations.
\end{tabular}

More intermarried immigrant women met Finnish relatives and/or friends at least once a month than did in-married immigrants $(86 \%$ vs. $66 \%, \mathrm{p}<.000)$. The clear tendency of intermarried women to have close networks with Finns could be traced by how many met every week: half of the intermarried women and one third of the inmarried women met Finnish relatives and/or friends every week ( $52 \%$ vs. $35 \%, \mathrm{p}<.000)$. One-tenth of the intermarried women met only Finns once a month. This could be interpreted as isolation from the co-ethnic community and potential dependency on the Finnish spouse's networks or other Finnish networks. It could be even interpreted as a tendency toward assimilation. It was rare for the in-married immigrant women to meet only Finns and no co-ethnics once a month (4\%). One-third of the in-married immigrants did not meet Finnish people even once a month, which was an indication of the social isolation of these immigrants from the host society. A small group of immigrant women from the FSU did not meet any relatives or friends even once a month and could be considered socially marginal ( $2 \%$ of in-married vs. $5 \%$ intermarried). 
Congruent with the previous results was the analysis of the ethnic background of the immigrants' close friends in Finland. Over half $(58 \%)$ of the in-married immigrant women who had Russian, Estonian or Finnish friends in Finland had only/mostly coethnic friends while the figure for those who were intermarried was $35 \%$. Intermarried immigrants had only/mostly Finnish friends twice as often (44\%) compared to inmarried immigrants (20\%). One both in- and intermarried woman out of four had an equal number of Finnish and co-ethnic friends. $(\mathrm{p}<.000$.) Intermarried immigrant women had close friend(s) in Finland somewhat more often than in-married immigrants $(84 \%$ vs. $80 \%, \mathrm{p}<.048)$.

Two logistic regression analyses were conducted to study social integration into the co-ethnic and the Finnish community separately. Those who met co-ethnic friends and/or relatives at least once a month were compared with those who did not (Appendix 2). A similar analysis was conducted of meetings with Finnish relatives and/or friends (Appendix 3). The main results of the analyses can be summarized as follows:

1) Age did not influence social integration in any marked or statistically significant way. This was not expected, because according to many studies integration is more difficult for older immigrants.

2) Estonian women were most often socially integrated into the Finnish community $(83 \%)$ compared with ethnic Finnish and Russian women (72-74\%). When proficiency in Finnish was controlled for, this difference decreased and was no longer statistically significant. The weak integration into the Finnish community of ethnic Finns and Russians seems to be mostly due to the language problems these groups face in Finland. While the Estonians were the most integrated group in regard to integration into the Finnish community, the opposite was the case regarding integration into the co-ethnic community. Seventy-nine percent of Estonian women and over 90 percent of both ethnic Finnish and Russian women were integrated into the co-ethnic network. After the other factors were controlled for, the Estonians were still less often socially integrated into the co-ethnic community compared with Russians and ethnic Finns.

3) Education did not have a systematic and statistically significant effect on social integration.

4) The survey analyses support the hypothesis that intermarriage is more favorable for integration into the Finnish community than is in-marriage ( $86 \%$ vs. $66 \%$ ). When other variables were held constant this connection diminished slightly, but remained statistically significant. On the other hand in-married immigrants were more closely in touch with co-ethnic networks compared to intermarried immigrants ( $94 \%$ vs. $86 \%$ ). This connection remained the same and statistically significant after the other factors were controlled for.

5) The year of migration had an important impact on social integration into the co-ethnic community. Almost everyone who migrated between 1994-1999 (94\%) was integrated into the co-ethnic community, but internal integration weakened 
with time. Only three out of four (78\%) of those who immigrated before the 1990s were integrated internally. This connection decreased somewhat after the other variables were controlled for, but remained important and statistically significant. At the same time social integration into the Finnish community increased with time. Three out of four of those who migrated in the 1990s were integrated into the Finnish community, but already 83 percent of those who migrated before the 1990s. The connection between integration into the Finnish community and the year of migration diminished and was no longer statistically significant, however, when other variables were controlled for.

6) Finnish language skills had an important impact on social integration into the Finnish community. Two-thirds of those who spoke Finnish moderately or poorly were integrated into the Finnish community, compared to as many as 81 percent of those who spoke Finnish well or very well. However, proficiency in Finnish had only a weak impact on integration into the co-ethnic community. This connection was not statistically significant after the other variables were controlled for.

7) Integration into the Finnish community was a little easier in the rural areas compared to urban areas ( $85-88 \%$ vs. $72 \%$ ), but it was somewhat more difficult for the immigrant women to integrate into the co-ethnic community in the sparsely populated rural areas ( $84 \%$ vs. urban $92 \%$ ). These connections diminished and were no longer statistically significant after the other factors were held constant.

\section{Segmented integration}

In Table 4 (next page) the results of segmented integration are presented. The concentration of integration into certain segments was clear. According to the analysis, marriage with a member of the dominant culture is more favorable for the integration process than is marriage to another immigrant. Half of the intermarried immigrants were both internally and externally integrated, but only one in five of the in-married women. The most common combination for in-married immigrant women $(40 \%)$ was social integration into both co-ethnic and Finnish networks, but weak economic integration. This combination was the second most common one among intermarried immigrant women (26\%).

One out of five in-married women, but only six percent of intermarried immigrant women had not gained economic integration or formed contacts with Finns, but were integrated into the co-ethnic networks. In-married immigrants were more closely in touch with co-ethnic networks than intermarried immigrants. More than one in ten of in-married women were economically well integrated and socially separated from the Finns. In contrast seven percent of the intermarried women seemed to be socially integrated only into the Finnish networks and economically integrated. The most marginal group of all - those who were economically and socially marginal in both networks - is very small: only one percent of both the in-married and intermarried women. 
Table 4. Segmented integration of in- and intermarried immigrant women from the FSU (percent).

\begin{tabular}{lcc}
\hline & In-marriage & Intermarriage \\
\hline Both networks \& economic integration & $22^{*}$ & 50 \\
Finnish network \& economic integration & 1 & 7 \\
Co-ethnic networks \& economic integration & 13 & 3 \\
Weak networks \& economic integration & 1 & 4 \\
Both networks \& weak economic integration & 40 & 26 \\
Finnish network \& weak economic integration & 2 & 3 \\
Co-ethnic networks \& weak economic integration & 20 & 6 \\
Weak networks \& weak economic integration & 1 & 1 \\
Total & 100 & 100 \\
Number of cases (N) & $\mathbf{5 9 5}$ & $\mathbf{5 0 6}$ \\
\hline Differencs betw
\end{tabular}

Differences between in- and intermarried immigrants are statistically significant at 5 percent risk level. Pearson Chi-Square was used for cross-tabulation.

\section{Discussion}

Many studies have presumed that intermarriage is problematic and generates marginality and isolation for immigrants (Cotrell 1990). This was not, however, the case in this study. The survey results support the hypothesis that integration is segmented and that marriage type has an independent impact on the segmented integration of immigrants. According to the results, intermarried immigrant women from the former Soviet Union seem to be more successful in finding access to the Finnish mainstream society compared to in-married immigrant women. Half of the intermarried and onefifth of the in-married immigrants have achieved both internal and external integration, i.e. social integration into the co-ethnic and Finnish community and economic integration into Finnish society. In-married immigrant women more often have economic limitations (poverty, unemployment and deficient housing) compared to intermarried immigrant women.

Although social integration into both Finnish and co-ethnic networks was the most common pattern for in- and intermarried women, a considerable number of in-married immigrants actually integrate only into co-ethnic networks, which are based on the language of their native country. Social separatism from the host society may empower the newcomers and the least integrated segments, yet, at the same time, it may hamper economic integration for many in-married immigrants. Social isolation from members of the host society and weak economical integration may have a negative impact on the future prospects of in-married immigrants and their children. On the other hand, among the intermarried immigrants social isolation from co-ethnics was somewhat more common than among in-married immigrants. Intermarriage does 
not, however, necessarily lead to external integration. Also some intermarried immigrants have economical problems, are unemployed and do not meet Finnish people every month. Limitations of external and internal integration may cause economic and social dependence on the Finnish spouses (Jaakkola 1994)

There are several reasons to expect intermarried immigrant women to be externally integrated more often than in-married immigrant women. First, the results indicated an educational selection of intermarried immigrant women. Intermarried women were younger when they moved to Finland, they had been living in the country longer and they spoke Finnish better than in-married immigrants, which put them in a better position regarding external integration. Intermarried women also lived more often in rural areas, where external integration seemed to be a little easier, compared to inmarried immigrants

Second, a Finnish spouse may assist in the immigration process, in obtaining a visa and in settling into a new place of residence. It seems that a Finnish husband can help his immigrant wife in the process of social mobility. It is possible for many an intermarried immigrant woman to move directly into a Finnish middle-class housing area, into a spacious apartment owned by the family, jumping several steps ahead and bypassing the bottom-up order traditional for immigration. Members of the host country can introduce the immigrant's spouse to new 'cultural milieus': Finnish culture, language and lifestyle. It seemed that the Finnish spouse had a significant role in the formation of the immigrant wife's networks and that they often at least partly had a shared network. Through her spouse the immigrant women gets to know different sides of Finnish society. This can be also problematic, because linguistic (and potentially cultural) inequality in the early years of marriage can cause conflicts and dependence on the spouse. (Tuomi-Nikula 1998, 20.)

There are also many other factors besides marriage type, which together or individually were connected to external and internal integration. Estonians seemed to be most often integrated into the Finnish community and economic life, but had the weakest co-ethnic connections. Ethnic Finns and Russians were strongly integrated into the co-ethnic community. Education had an impact on economic integration, but not on social integration. The economic situation of immigrant women improved year by year. Their integration into the co-ethnic community weakened and integration into the Finnish community grew somewhat stronger the longer they lived in Finland. The establishment of friendships with the members of the host society takes time among first-generation immigrants. On the other hand, a long period of residence is by no means a guarantee that friendships will be made with Finns. (See also Jaakkola 1983, 51-95; Jaakkola 1984, 31-38.) Finnish language skills were an important factor accelerating external integration. Linguistic ability in the host language does not, however, entail total rejection of one's own ethnic group (see also Jaakkola 1983, 51-95; Jaakkola 1984, 31-38). 
Given the scanty knowledge available about intermarriage and its connections to discrimination and feelings of marginality and dependence potentially experienced by foreign spouses in Finland, and the detailed connections of intermarriages to social networks, future studies are both necessary and urgent.

\section{Acknowledgments}

The author wishes to thank members of the research project 'Developing theory and methodology in the study of the effects of discrimination and marginalization', Professor Kari Pitkänen and others who have commented on earlier versions of this article.

\section{References}

Berry, John W. 1997. Immigration, acculturation, and adaptation. Applied Psychology: An International Review, 46(1), pp. 5-68.

Breger, Rosemary and Rosanna Hill. 1998. Preface. In: Cross-cultural marriage: identity and choice, edited by Rosemary Breger and Rosanna Hill, pp. 1-32. New York and Oxford:Berg.

Carmon, Naomi. 1996. Introduction. In: Immigration and integration in post-industrial societies. Theoretical analyses and policy-related research, edited by Naomi Carmon. Hampshire London: Macmillan Press, pp. 1-10.

Castrén, Anna-Maija. 2001. Perhe ja työ Helsingissä ja Pietarissa - Elämänpiirit ja yhteiskunta opettajien sosiaalisissa verkostoissa. [Family and work in Helsinki and St. Petersburg - Social circles and societies in the social networks of teachers.] Helsinki: Finnish Literature Society.

Cottrell, Ann Baker. 1990. Cross-national marriages: a review of the literature. Journal of Comparative Family Studies Vol. XXI, No. 2, pp. 151-169.

Dietz, Barbara. 2000. German and Jewish migration from the former Soviet Union to Germany: background, trends and implication. Journal of Ethnic and Migration Studies Vol. 26, No. 3, pp. 635-652.

Ekholm, Elina. 1994. Syrjäytyä vai selviytyä - pakolaisten elämää Suomessa. [Marginalization or survival - refugee life in Finland.] Sosiaali- ja terveysministeriön selvityksiä 9. Helsinki: Painatuskeskus Oy.

Forsander, Annika. 2001. Etnisten ryhmien kohtaaminen. [Encountering ethnic groups.] In: Monietnisyys, yhteiskunta ja työ, edited by Annika Forsander, Elina Ekholm, Petri Hautaniemi, Abdullahi Ali, Anne Alitolppa-Niitamo, Eve Kyntäjä and Nguyen Quoc Cuong, pp. 31-56. Helsinki: Palmenia.

Gordon, Milton M. 1964. Assimilation in American life: the role of race, religion, and national origins. New York: Oxford University Press.

Imamura, Anne. 1990. Strangers in a strange land: coping with marginality in international marriage. Journal of Comparative Family Studies Vol. XXI, No. 2, pp. 171-191.

Jaakkola, Magdalena. 2000. Finnish attitudes toward immigrants in 1987-1999. Yearbook of Population Research in Finland 36: pp. 129-161.

Jaakkola, Magdalena. 1983. Finnish immigrants in Sweden: Networks and life styles. Research Group for Comparative Sociology, University of Helsinki, Research Reports No 30.

Jaakkola, Magdalena. 1994. Puolalaiset Suomessa. [Poles in Finland.] In: Maahanmuuttajat Kulttuurien kohtaaminen Suomessa, edited by Karmela Liebkind. Helsinki: Gaudeamus. 
Jaakkola, Magdalena. 1984. Siirtolaiselämää. Tutkimus ruotsinsuomalaisista siirtolaisyhteisönä. [Immigrant life: Networks, lifestyles and ethnic mobilization of Finnish immigrants in Sweden.] Sosiaalipolitiikka 1984, 53-108.

Jasinskaja-Lahti, Inga. 2000. Psychological acculturation and adaptation among Russianspeaking immigrant adolescents in Finland. Social psychological studies 1, Department of Social Psychology, University of Helsinki.

Jasinskaja-Lahti, Inga, Karmela Liebkind, and Tiina Vesala. 2002. Rasismi ja syrjintä Suomessa. Maahanmuuttajien kokemuksia. [Racism and discrimination in Finland - immigrants' experiences.] Helsinki: Gaudeamus.

Kauppinen, Timo. 2000. Maahanmuuttajien segregaatio pääkaupunkiseudulla 1990-luvun lopussa. [Segregation of immigrants in the capital area at the end of the 1990s.] Kvartti 3/ 2000, pp. 39-49.

Kyntäjä, Eve. 1997. Ethnic remigration from the former Soviet Union to Finland-patterns of ethnic identity and acculturation among the Ingrian Finns. Yearbook of Population Research in Finland 34, pp. 102-113.

Laari, Outi. 1997. Suomi ja inkerinsuomalaiset - etnisyys velvoittaa? [Finland and Ingrian Finns - obligation of ethnicity?] Tiede ja edistys 4/1997, pp. 302-316

Padilla, Amado. 1980. The role of cultural awareness and ethnic loyalty in acculturation. In: Acculturation, Theory, Models and Some New Findings, edited by Amado Padilla.

Portes, Alejando and Min Zhou. 1993. The new second generation: segmented assimilation and its variants among post-1965 immigrant youth. Annals of the American Academy of Political and Social Science 530: 74-96.

Schierup, Carl-Ulrik and Aleksandra Ålund. 1987. Will they still be dancing? Integration and ethnic transformation among Yugoslav immigrants in Scandinavia. Stockholm: Almqvist \& Wiksell International.

Shuval, Judith T. 1998. Migration to Israel: the mythology of 'uniqueness'. International Migration 36 (1): 3-26.

Statistics Finland. 2002. Ulkomaalaiset ja siirtolaisuus 2001 -. Foreigners and international migration 2001. Helsinki: Statistics Finland.

Tuomi-Nikula, Outi. 1988. Acculturation in the ethnic mixed marriage. Examples provided by Finns married in the Federal Republic of Germany. Ethnologia Fennica 16, 5-26.

Ylänkö, Maaria. 1997. Afrikkalaisten integraationäkymät - pohdintoja Suomen lähtökohdista vastaanottajamaana. [Integration prospects of Africans in Finland - Finland as a host country.] In: Sovussa vai syrjässä? Ulkomaalaisten integroituminen Helsinkiin, edited by Harry Shulman and Vesa Kanninen, pp. 27-58. Helsingin kaupungin tietokeskuksen tutkimuksia 1997:12.

Zhou, Min. 1997. Segmented assimilation: issues, controversies, and recent research on the new second generation. International Migration Review 31 (4): 975-1008. 
Appendix 1. Models of economic integration of immigrant women from the FSU (odds ratio,

logistic regression).

\begin{tabular}{|c|c|c|c|c|c|c|c|}
\hline & \multicolumn{6}{|c|}{ Economic integration } & \multirow[b]{2}{*}{$\begin{array}{l}\text { Model } 7 \\
\text { OR } \\
\end{array}$} \\
\hline & $\begin{array}{l}\text { Model 1 (\%) } \\
\text { OR } \\
\end{array}$ & $\begin{array}{l}\text { Model } 2 \\
\text { OR } \\
\end{array}$ & $\begin{array}{l}\text { Model } 3 \\
\text { OR } \\
\end{array}$ & $\begin{array}{l}\text { Model } 4 \\
\text { OR } \\
\end{array}$ & $\begin{array}{l}\text { Model } 5 \\
\text { OR } \\
\end{array}$ & $\begin{array}{l}\text { Model } 6 \\
\text { OR } \\
\end{array}$ & \\
\hline \multicolumn{8}{|l|}{ Age } \\
\hline $18-29$ years & $1.00(52)$ & 1.00 & 1.00 & 1.00 & 1.00 & 1.00 & 1.00 \\
\hline $30-39$ years & $1.01(53)$ & 1.01 & 0.88 & 0.91 & 0.76 & 0.80 & 0.80 \\
\hline $40-65$ years & $0.70 *(43)$ & $0.70^{*}$ & $0.65 *$ & $0.72 *$ & $0.57^{*}$ & $0.61^{*}$ & $0.62 *$ \\
\hline \multicolumn{8}{|l|}{ Ethnic background } \\
\hline Russian & $1.00(50)$ & 1.00 & 1.00 & 1.00 & 1.00 & 1.00 & 1.00 \\
\hline Estonian & $1.49 *(60)$ & $1.39 *$ & $1.52 *$ & $1.45 *$ & 1.27 & 1.06 & 1.05 \\
\hline Finnish (descent) & $0.63 *(39)$ & $0.63 *$ & $0.69^{*}$ & 0.97 & 0.87 & 0.78 & 0.77 \\
\hline \multicolumn{8}{|l|}{ Education } \\
\hline Primary school (or less) & $1.00(40)$ & & 1.00 & 1.00 & 1.00 & 1.00 & 1.00 \\
\hline Vocational/High school & $1.16(43)$ & & 1.14 & 1.26 & 1.24 & 1.24 & 1.23 \\
\hline University/High occupation & $1.96 *(56)$ & & $2.00 *$ & $2.13 *$ & $2.10^{*}$ & $2.06 *$ & $2.04 *$ \\
\hline \multicolumn{8}{|l|}{ Ty pe of marriage } \\
\hline Immigrant & $1.00(36)$ & & & 1.00 & 1.00 & 1.00 & 1.00 \\
\hline Finnish & $3.03 *(63)$ & & & $2.71 *$ & $2.53 *$ & $2.27 *$ & $2.27 *$ \\
\hline \multicolumn{8}{|l|}{ Year of migration } \\
\hline $1948-1989$ & $1.00(70)$ & & & & 1.00 & 1.00 & 1.00 \\
\hline $1990-1994$ & $0.48 *(53)$ & & & & 0.63 & 0.66 & 0.66 \\
\hline $1995-1999$ & $0.29 *(41)$ & & & & $0.34 *$ & $0.39 *$ & $0.39 *$ \\
\hline \multicolumn{8}{|l|}{ Finnish language proficiency } \\
\hline Speaks moderately or poorly & $1.00(36)$ & & & & & 1.00 & 1.00 \\
\hline Speaks well or very well & $2.36 *(58)$ & & & & & $1.55 *$ & $1.56^{*}$ \\
\hline \multicolumn{8}{|l|}{ Place of residence } \\
\hline Urban & $1.00(46)$ & & & & & & 1.00 \\
\hline Rural, densely populated & $1.96 *(63)$ & & & & & & 1.29 \\
\hline Rural, sparsely populated & $1.21(51)$ & & & & & & 0.84 \\
\hline Significance of the model & & 0.000 & 0.000 & 0.000 & 0.000 & 0.000 & 0.000 \\
\hline Number of cases $(\mathrm{N})$ & 1,269 & 1,218 & 1,218 & 1,218 & 1,218 & 1,218 & 1,218 \\
\hline
\end{tabular}

*The probability of integration differs from the reference group at a significance level of 5 percent

Model 1 includes only the variable in question. Model 2 includes age and ethnic background. Model 3 includes the previous variables and education.

Model 4 includes the previous variables and nationality of the spouse. Model 5 includes the previous variables and year of migration. Model 6 includes

the previous variables and Finnish language proficiency. Model 7 includes the previous variables and place of residence. 
Appendix 2. Models of social integration of immigrant women from the FSU into the Finnish community (odds ratio, logistic regression).

\begin{tabular}{|c|c|c|c|c|c|c|c|}
\hline & \multicolumn{7}{|c|}{ Social integration into the Finnish community } \\
\hline & $\begin{array}{l}\text { Model } 1(\%) \\
\text { OR }\end{array}$ & $\begin{array}{l}\text { Model } 2 \\
\text { OR }\end{array}$ & $\begin{array}{l}\text { Model } 3 \\
\text { OR }\end{array}$ & $\begin{array}{l}\text { Model } 4 \\
\text { OR } \\
\end{array}$ & $\begin{array}{l}\text { Model } 5 \\
\text { OR }\end{array}$ & $\begin{array}{l}\text { Model } 6 \\
\text { OR }\end{array}$ & $\begin{array}{l}\text { Model } 7 \\
\text { OR }\end{array}$ \\
\hline \multicolumn{8}{|l|}{ Age } \\
\hline $18-29$ years & $1.00(77)$ & 1.00 & 1.00 & 1.00 & 1.00 & 1.00 & 1.00 \\
\hline $30-39$ years & $0.99(77)$ & 0.99 & 1.02 & 0.99 & 0.97 & 1.04 & 1.04 \\
\hline $40-65$ years & $0.86(73)$ & 0.88 & 0.91 & 0.94 & 0.91 & 0.99 & 0.96 \\
\hline \multicolumn{8}{|l|}{ Ethnic background } \\
\hline Russian & $1.00(74)$ & 1.00 & 1.00 & 1.00 & 1.00 & 1.00 & 1.00 \\
\hline Estonian & $1.76 *(83)$ & $1.71 *$ & $1.65^{*}$ & $1.59 *$ & $1.57^{*}$ & 1.24 & 1.26 \\
\hline Finnish (descent) & $0.92(72)$ & 0.91 & 0.87 & 1.29 & 1.29 & 1.10 & 1.13 \\
\hline \multicolumn{8}{|l|}{ Education } \\
\hline Primary school (or less) & $1.00(77)$ & & 1.00 & 1.00 & 1.00 & 1.00 & 1.00 \\
\hline Vocational/High school & $0.97(76)$ & & 1.01 & 1.24 & 1.24 & 1.30 & 1.27 \\
\hline University/High occupation & $0.82(73)$ & & 0.81 & 0.91 & 0.92 & 0.92 & 0.92 \\
\hline \multicolumn{8}{|l|}{ Type of marriage } \\
\hline Immigrant & $1.00(66)$ & & & 1.00 & 1.00 & 1.00 & 1.00 \\
\hline Finnish & $3.07 *(86)$ & & & $3.17^{*}$ & $3.10^{*}$ & $2.78^{*}$ & $2.52 *$ \\
\hline \multicolumn{8}{|l|}{ Year of migration } \\
\hline $1948-1989$ & $1.00(83)$ & & & & 1.00 & 1.00 & 1.00 \\
\hline $1990-1994$ & $0.61(75)$ & & & & 0.86 & 0.91 & 0.89 \\
\hline $1995-1999$ & $0.57 *(74)$ & & & & 0.81 & 0.99 & 0.96 \\
\hline \multicolumn{8}{|c|}{ Finnish language proficiency } \\
\hline Speaks moderately or poorly & $1.00(67)$ & & & & & 1.00 & 1.00 \\
\hline Speaks well or very well & $2.15^{*}(81)$ & & & & & $1.75^{*}$ & $1.69 *$ \\
\hline \multicolumn{8}{|l|}{ Place of residence } \\
\hline Urban & $1.00(72)$ & & & & & & 1.00 \\
\hline Rural, densely populated & $2.98 *(88)$ & & & & & & 1.92 \\
\hline Rural, sparsely populated & $2.15 *(85)$ & & & & & & 1.49 \\
\hline Significance of the model & & 0.024 & 0.034 & 0.000 & 0.000 & 0.000 & 0.000 \\
\hline Number of cases $(\mathrm{N})$ & 1,199 & 1,159 & 1,159 & 1,159 & 1,159 & 1,159 & 1,159 \\
\hline
\end{tabular}

*The probability of integration differs from the reference group at a significance level of 5 percent

Model 1 includes only the variable in question. Model 2 includes age and ethnic background. Model 3 includes the previous variables and education.

Model 4 includes the previous variables and nationality of the spouse. Model 5 includes the previous variables and year of migration. Model 6 includes

the previous variables and Finnish language proficiency. Model 7 includes the previous variables and place of residence. 
Appendix 3. Models of social integration of immigrant women from the FSU into the co-ethnic community (odds ratio, logistic regression).

\begin{tabular}{|c|c|c|c|c|c|c|c|}
\hline & \multicolumn{7}{|c|}{ Social integration into the co-ethnic community } \\
\hline & $\begin{array}{l}\text { Model } 1(\%) \\
\text { OR }\end{array}$ & $\begin{array}{l}\text { Model } 2 \\
\text { OR }\end{array}$ & $\begin{array}{l}\text { Model } 3 \\
\text { OR }\end{array}$ & $\begin{array}{l}\text { Model } 4 \\
\text { OR }\end{array}$ & $\begin{array}{l}\text { Model } 5 \\
\text { OR }\end{array}$ & $\begin{array}{l}\text { Model } 6 \\
\text { OR }\end{array}$ & $\begin{array}{l}\text { Model } 7 \\
\text { OR }\end{array}$ \\
\hline \multicolumn{8}{|l|}{ Age } \\
\hline $18-29$ years & $1.00(93)$ & 1.00 & 1.00 & 1.00 & 1.00 & 1.00 & 1.00 \\
\hline $30-39$ years & $0.69(91)$ & 0.71 & 0.69 & 0.66 & 0.74 & 0.76 & 0.78 \\
\hline $40-65$ years & $0.60(89)$ & $0.56^{*}$ & $0.55^{*}$ & $0.49^{*}$ & 0.60 & 0.61 & 0.65 \\
\hline \multicolumn{8}{|l|}{ Ethnic background } \\
\hline Russian & $1.00(93)$ & 1.00 & 1.00 & 1.00 & 1.00 & 1.00 & 1.00 \\
\hline Estonian & $0.28 *(79)$ & $0.26^{*}$ & $0.26^{*}$ & $0.27^{*}$ & $0.29 *$ & $0.28^{*}$ & $0.27^{*}$ \\
\hline Finnish (descent) & $0.93(93)$ & 0.94 & 0.94 & 0.59 & 0.63 & 0.61 & 0.60 \\
\hline \multicolumn{8}{|l|}{ Education } \\
\hline Primary school (or less) & $1.00(86)$ & & 1.00 & 1.00 & 1.00 & 1.00 & 1.00 \\
\hline Vocational/High school & $1.76(91)$ & & 1.88 & 1.70 & 1.89 & 1.88 & 1.89 \\
\hline University/High occupation & $1.53(90)$ & & 1.74 & 1.69 & 1.91 & 1.88 & 1.84 \\
\hline \multicolumn{8}{|c|}{ Type of marriage } \\
\hline Immigrant & $1.00(94)$ & & & 1.00 & 1.00 & 1.00 & 1.00 \\
\hline Finnish & $0.34 *(86)$ & & & $0.32^{*}$ & $0.34^{*}$ & $0.34 *$ & $0.36^{*}$ \\
\hline \multicolumn{8}{|l|}{ Year of migration } \\
\hline $1948-1989$ & $1.00(78)$ & & & & 1.00 & 1.00 & 1.00 \\
\hline $1990-1994$ & $2.30 *(89)$ & & & & 1.50 & 1.52 & 1.57 \\
\hline $1995-1999$ & $4.21 *(94)$ & & & & $2.38^{*}$ & $2.48^{*}$ & $2.56^{*}$ \\
\hline \multicolumn{8}{|l|}{ Finnish language proficiency } \\
\hline Speaks moderately or poorly & $1.00(94)$ & & & & & 1.00 & 1.00 \\
\hline Speaks well or very well & $0.51 *(88)$ & & & & & 1.12 & 1.13 \\
\hline \multicolumn{8}{|l|}{ Place of residence } \\
\hline Urban & $1.00(92)$ & & & & & & 1.00 \\
\hline Rural, densely populated & $0.83(90)$ & & & & & & 1.20 \\
\hline Rural, sparsely populated & $0.47 *(84)$ & & & & & & 0.61 \\
\hline Significance of the model & & 0.000 & 0.000 & 0.000 & 0.000 & 0.000 & 0.000 \\
\hline Number of cases $(\mathrm{N})$ & 1,309 & 1,252 & 1,252 & 1,252 & 1,252 & 1,252 & 1,252 \\
\hline
\end{tabular}

*The probability of integration differs from the reference group at a significance level of 5 percent

Model 1 includes only the variable in question. Model 2 includes age and ethnic background. Model 3 includes the previous variables and education.

Model 4 includes the previous variables and nationality of the spouse. Model 5 includes the previous variables and year of migration. Model 6 includes the previous variables and Finnish language proficiency. Model 7 includes the previous variables and place of residence. 